\title{
OOR DIE VERHOUDING TUSSEN TEOLOGIESE SOSIALE ETIEK EN SOSIOLOGIE, MET VERWYSING NA DIE KIRCHLICHE DOGMATIK VAN KARL BARTH
}

\author{
DS. J. S. KRÜGER
}

„Die Sachlichkeit der Theologie besteht darin, dasz sie sich die Auslegung der Offenbarung zu ihrer einzigen Aufgabe macht!" - (K.D. II/1, 228).

VOOROPMERKING: Wat hier volg, is iets oor die verhouding tussen teologiese sosiale etiek en sosiologie, soos dit op die standpunt van Karl Barth daar sou uitsien. Dit maak nie aanspraak op volledigheid nie, en wat veral sal opval, is dat dit nogal abstrak en formeel van aard is. Dit is die gevolg van ' $n$ tweërlei inperking.

Eerstens veronderstel dit slegs die samehang met die meer inhoudelike teologiese temas soos die skepping en antropologie (wat Barth betref: veral die tema van die „Mitmenschlichkeit”); die voorsienigheid (teologie van die geskiedenis, die kosmiese betekenis van Christus); die ekklesiologie (die orde en inrigting van die kerk, die verhouding van die kerk tot die wêreld, die sogenaamde Twee Rykeleer, ensovoorts); die eskatologie, die leer van die gebod van God, en, natuurlik in diepste instansie, die christologie, sonder dat hierdie temas as sodanig behandel word. Dit sal naamlik 'n veel breër behandeling vereis as wat hier moontlik is.

Tweedens is dit nogal abstrak in die sin dat dit nie $r$ irek afgestem is op 'n spesifieke, konkrete, maatskaplike probleem (die huwelik of die arbeid) nie wat dit verder aan „lewendigheid" laat inboet.

Met hierdie inperkinge en beperkinge vooropgestel, wil dit egter 'n poging wees om 'n konkrete weergawe van die gedagtes van Barth te wees. 
Die metode wat gevolg word, is om ná 'n inleiding heel uitvoerig uit die KD self te siteer betreffende drie punte, naamlik die saaklikheid van die teologie as wetenskap, die trefwydte van die teologie ten aansien van die werklikheid, en die standpunt van die teologiese etiek ten aansien van allerlei (sosiale) wetmatighede, terwyl die geheel afgesluit word deur 'n aantal samevattende stellinge.

Die bedoeling is nie soseer om 'n bydrae tot die gesprek oor hierdie belangrike saak te maak nie, maar slegs om nog bietjie materiaal aan te dra vir 'n gesprek tussen teologie en sosiologie wat by ons te lande nog nie na wense op dreef gekom het nie. Vandaar die metode. Vandaar ook dat die standpunt van Barth slegs weergegee word, dus sonder kritiek. Dat daar 'n besonder groot mate van waardering vir sy standpunt bestaan, sal wel blyk, maar word hier tog eerlikheidshalwe aan die begin in ronde woorde gesê.

\section{INLEIDING:}

Soos die woord teologie letterlik aandui, is die spreke, die leer of die wetenskap van "God") die kern en sentrum van die wetenskaplike arbeid waarin die Kerk vir haarself en na buite, rekenskap aflê van haar geloof. Waar álles op aankom, is die christelike spreke oor Hom: die teologie het naamlik slegs te make met die wese en bestaan van God in samehang met 'n bepaalde geskiedenis, naamlik sy openbaring in Christus. En juis vanuit die aard van hierdie sentrale primêre „objek" van die teologie - die drieënige God en Skepper, Versoener en Verlosser vanuit Wie, en oor Wie die teologie spreek - moet 'n sekondêre, korrelatiewe objek aanvaar word waaroor (nie

1. Hermann Diem. Theologie als kirchliche Wissenschaft. München 1955, 21.J. van den Berg (Theoloog en Theologie, Vox Theologica 37, 1967), 72-86 dui as voorwerp van die teologie in toenemende radikalisering aan: die religieuse ervaring, die openbaring en, as mees toegespitste en uiterste konsekwensie, God Sien dr. J. A. Heyns, Die Grense van die Teologie, in: Die Waardes van die Afrikaner, Referate gelewer by die jaarvergadering van die Suid-Afrikaanse Akademie vir Wetenskap en Kuns, 1968. Die objek van die teologie is: die openbaring van God, die Heilige Skrif en die belydenisskrifte (God is nie in direkte sin voorwerp van die teologie nie) 
van waaruit) die teologie spreek, naamlik die wêreld as voorwerp van sy skeppende, versoenende en verlossende handele die ganse werklikheid in al sy dele, dus inklusief die verhouding van mens tot medemens, met ander woorde die sosiale werklikheid.

Daarmee is onder andere die belangrike tema aangesny van die aard en draagwydte van teologiese uitsprake oor die sosiale strukture. Dit kan ook geformuleer word as die vraag na die sosiale aspekte van die teologie en sy verhouding tot ander, naamlik die sosiale wetenskappe ${ }^{2}$ ), waaronder ons heel in die algemeen dié groep van wetenskappe verstaan wat met ervaringswetenskaplike middele analiserend en generaliserend besig is met die enigsins stabiele strukture en prosesse in die verhouding tussen indiwidue, individue en groepe onderling; met die daaraan ten grondslag liggende norme of waardes; met die filosofiese bearbeiding van die wetenskaps-teoretiese en kenteoretiese grondslae daarvan en die sintetisering van die aspektiewe, parsiële kennis tot 'n totaalvisie van die sosiale werklikheid ${ }^{3}$ ).

2. Die probleem waarmee ons ons besig hou. is wat dr. Heyns belianclel as die laaste van die grense van die teologie (a.w. 83.84). Hierdie grensgebied het twee kante, nl. eerstens die godsdienssosiologie (die beweging van die sosiologie in die rigting en op die terrein van die Kerk) en die sosiale etiek (die beweging van die teologie in die rigting en op die terrein van die maatskappy). Veral lg. kant interesseer ons hier.

3. Vgl. die algemene definisie van G. Heilfurth, Ev. Soz-lex, Stuttgart 1954, 976. Aangesien hierdie geen sosiologiese voordrag probeer wees nie, ag ons ons ontslaan van die noodsaak om in te gaan op die omskrywing van die presiese veld(e) van sosiologiese ondersoek. As verteenwoordigend vir ' $n$ plasing van die sosiologie te midde van die wetenskappe en die verhouding to ${ }^{\prime}$ die aangrensende dissiplines soos psigologie. regswetenskap, ens., sien J. A. A. van Doorn en C. J. Lammers, Moderne Sociologie. Systematiek en Analyse, Utrecht 1966, 15 vv. Vir die verhouding tussen sosiologie en filosofie, verwys ons na H. Schelsky, Ortsbestimmung der deutschen Soziologie, DüsseldorfKöln 1959, 98 vv. en, krities daarteenoor, R. F. Beerling, Wijsgerigsociologische Verkenningen, Eerste bundel, Zeist/Arnhem 1964, 20 vv. Die oorsaak van die onklaarheid oor die afbakening van die veld(e) van ondersoek moet nie slegs gesoek word in die kort geskiedenis van die sosiologie nie, maar ook in die feit dat álle wetenskappe wat die mens tot voorwerp het, vandag in mindere of meerdere mate deur die sosiologie geaffekteer is. 
Die huidige aktualiteit van die gesprek tussen teologie en die sosiale wetenskappe ${ }^{4}$ ) die noodsaak én die problematiek daarvan, is die konsekwensie van 'n lang historiese ontwikkeling in die moderne tyd:

(1) Eerstens wys ons op die aftakening van die eeue-oue, sogenaamde organisasie, primêre samelewingstrukture, van die feodaal-agrriese, voorindustriële, statiese ordeninge en die vervanging daarvan deur die segenaamde sekondere, dinamiese, funksionele, mobiele strukture van die geinndustrialiseerde maatskappy ${ }^{5}$ ). Hierdie omwentelinge (op die terreine van byvoorbeeld die familie, die staat, die arbeid, ensovoorts) het die ontwikkeling van wetenskappe gestimuleer wat hierdie sosiale prosesse tot

'. Uit die oorvloed van literatuur verwys ons na 'n paar titels. Uit Nederland: $R$. van Dijk, Mens en Medemens; een inleiding tot die algemene sociologie, Wagemagen, 1955; W. Banning. Theologie en Sociologie, Van Genkom. Assen 1936. R. Kooistra, De Geref. Theoloog en de Sociologie, diss. Vrije Universiteit, T. Wever, Franeker, 1955; J. C. Hoekendyk, Kerk en Volk in de Duĩtse Zendingswetenschap, waarin hy o.a. die stelling maak dat dit 'n blyk van teologiese erns is, wanneer mens in sosiologiese vrae nie onmiddellik verkap teologies nie, maar so suiwer moontlik sosiologies sou probeer dink; H. D. de Loor: Hoekendijk en verder .... Charllonreeks Nr. 51, en: Soziologie und Theologie (ZEE jg. 5, 1966, 159 vv.) Dr. G. Dekker, Sociologie en Kerk - Over het recht en het nut van die sociologie met betrekking tot die Kerk, J. H. Kok, Kampen, 1969. Wat Duistland betref, verwys ons na die werke van $\mathbf{H}$. Schelsky, o.a.: Ist Dauerreflexion institutionalisierbar? Zum Thema einer modernen Religionssoziologie, Zeitschrift für Evangelische Ethik 1957, (jg. 1), 153 vv.; Die skeptische Generation. Düsseldorf-Köln. 1957, 523 vv.; Ortsbestimmung der deutschen Soziologie, Düsseldorf-Köln. 1959; Religionssoziologie und Theologie, ZEE 1959. 129 vy.; Auf der Suche nach Wirklichkeit, Gesammelte Aufsätze, 1965. R. Lindner: Theologie der Gesellschaft und Ethik, in: Kirche in der Zeit, jg. 17, 1962, 306 vv.; Uber die Zusammenarbeit von Soziologie und Theologie, ZEE 1966, 65 vv. H. D. Wendiand se werke, o.a. Das System der funktionalen Gesellschaft und die Theologie, in: Kerygma und Dogma jg. 2, 1956; Die Kirche in der modernen Gesellschaft. Entscheidungsfragen für das kirchliche Handeln im Zeitalter der Massenwelt. Hamburg 1957; Einführung in die Sozialethik, Sammlung Göschen; Die Kirche in der revolutionären Gesellschatf. Sozialethische Aufsätze und Reden. Gütersloher Verlogshaus, 1967. M. Greiffenhagen: Die Vestehens problematik im Dialog zwishen Soziologie und Theologie. unter sucht am Beispiel der Institution. ZEE je. 4, 1960. 159 vv. H. Weber, Theologie der Gesellschaft als Soziallehre und Sozialethik, ZEE jg. 10, 1966, 236 vv. Trouens, elke jaargang van ZEE bied 'n groot voorraad nuwe literatuur. Belangrik is ook die artikels van W. Schweitzer, o.a. in ZEE jg. 5, 1961, 56 vv., en ZEE jg. 3, 1959. 195 vv.: ..Menschliche Wirklichkeit in theologischer und soziologischer Sicht." Ook in die ekumeniese diskussies van die Wêreldraad van Kerke geniet hierdie grensproblematiek steeds meer aandag, vgl. bv. Het Sociale Denken in die Oecumene. Enkele oecumenische studies en rapporten uit de periode 1948-1956, Boekencentrum. 's-Gravenhage. 1957. Vgl. ook Walter G. Muelder, Theologie und Sozialwissenschaft, in: Die Kirche als Faktor einer kommenden Weltgemeinschaft. Kreuz-Verlag. Stuttgart-Berlin. 1966, 68 vv.; R. Mehl, Die Grundlage der christlichen Sozialethik, en Paul Abrecht, Die Entwicklung einer ökumenischen Sozialethik (albei in dieselfde bundel).

5. Vir hierdie ,.epochale Sozialstruktur" sien H. Schelsky, Die skeptische Generation, Düsseldorf-Köln 1957, 21 vv. 
objek van studie maak. Die sosiologie is dus die resultaat van, en die reflekteer die veranderinge van die moderne maatskappy.

In sekere sin is die sosiologie dus die produk van die desintegrasie van die middeleeuse samelewing (dink maar onder andere aan die betekenis van die industriële rewolusie). Die verhouding van die teologie en kerk ten opsigte van daardie orde is natuurlik histories heel anders: die kerk was juis die bekroning van daardie orde. Dit is slegs in die jongste tyd dat die teologie bewus begin raak daarvan dat die kerk weer „Exodusgemeinde” (Moltmann) word, of liewer: in wese is (1 Petr. 2:11: vreemdelinge en bywoners).

(2) Die gees waarin hierdie nuwe besinning van die begin af aan bedryf is, staan weer in die lyn van 'n ander, en ouer, proses van ontbinding wat sig oëskynlik nog steeds voltrek in 'n onafwendbare gang, naamlik die ontbinding van dié harmoniese lewensbeskouing wat die ou ordes as kosmiese, goddelike ordes gesanksioneer het. Ons bedoel die proses van "sekuralisasie", die verval van die sogenaamde „corpus christianum.” Die ontbinding van die "corpus christianum" is terselfdertyd die ontbinding van 'n eenheidlike corpus scientiarum onder die hegemonie van die teologie. Die nuwe era beleef die „ontvoogding" en "mondigwording" van die natuurwetenskap, die regswetenskap, die filosofie, ensovoorts ${ }^{6}$ ). In die sosiologie ontmoet die teologie nou 'n wetenskap wat vanweë sy relatiewe jonkheid"a) hierdie tradisionele binding nooit geken het nie.

(3) Kragtens sy afkoms is die sosiologie nie slegs „vreemd" ten aansien van die teologie in soverre die sosiologie vreemd is ten aansien van die ou, statiese sosiale orde en in soverre dit

'i. J. de Graaf en R. Baklicr, De mondige Mens lussen Goed en Kwaad, Utrecht 1961 . bied 'n kernagtige samevatting van hierdie verloop.

Vgl. Peter L. Berger: Het hemels baldakijn (Amboboeken Utrecht, 1969, vertaling uit die Amerikaans: The Sacred canopy, 1967) 119-189. Met sekularisacie bedoel hy die proses waardeur sektore van samelewing en kul.uur onttrek is aan die oorheersing van godsdienstige institusies en simbole (a.w. 123). Sameleving, institusies: Dit dui op die sosiaal-strukturele proses van verlies van kontrole of invloed deur die kerk. Kultuur, simbole: dit dui op die totaliteit van kultuurlewe en ideevorming, soos dit waargeneem word in die afneem van religieuse inhoude in die kuns, die filosofie, die letterkunde en die wetenskap.

"a. Die sosiale denke gaan weliswaar terug tot op Plato en Aristoteles, maar die sosiologie is tog eintlik 'n kind van die 19e eeu (Comte); die sosiologie waarmee die teologie vandag te doene het, het veral ná die Tweede Wereldoorlog na vore gekom, gestempel vanuit die V.S. $\Lambda$. 
vreemd is ten aansien van 'n eenheidlike christelike lewensbeskouing en wetenskapsbeskouing waarin die teologie en die sosiologie rimpelloos geharmonieseer kan word nie, maar dit is ook ' $n$ vreemdeling ten aansien van enige denke in terme van ewige, onhistoriese synswaarhede ${ }^{i}$ ).

\section{As erfgenaam van die Aufkläring en die historiese besef van} die moderne mens vir wie taal, reg, godsdiens, sede en kuns groothede is wat ,geschichtlich", deur mense, gerealiseer word, sien die sosiologie die tussen-menslike strukture (ook die Kerk) nie as irrasioneel te anvaarde, metafisiesverankerde groothede nie, maar hy sien dit onder die gesigspunt van rasionele analise en die voortgaande strukturering daarvan as 'n saak van rasionele „planning". W. Schweitzer (ZEE 1959, 202 vv.) spreek dan ook van "die Entzauberung unserer Winklichkeit durch die Zoziologie". Dit bring natuurlik mee dat die menslike verantwoordelikheid in ons tyd swaar belas word. Die worsteling van die teologie om 'n aangrypingspunt met die sosiologie is ' $n$ faset van die worsteling van die teologie met die probleem van die historisme'a(. Net so weinig as die teologie in sy eksegetiese arbeid die historiese kritiek kan ignoreer, net so weinig mag die teolo-

i. Sien bv. F. Flückiger, Geschichte des Naturrechtes I. (Die Geschichte der eutopäischen Rechtsidee im Altertum und (Frühmittelalter), Zollikon-Zürich 1954. 239 vv. oor die intieme samehang van teologie, feodalisme en Griekse Neoplatonisme in die maatskappyleer van die middeleeuse Kerk.

ia. Ons verwys hier na die geskiedenisteologie van Wolfhard Pannenberg wat juis met hierdie probleem besig is, en daarmee poog om die aporieë in die denke van Troeltsch te oorwin. In hierdie verband is belangrik sy artikel in ZEE jg. 7, 1963; Zur Theologie des Rechtes. Sien H. H. Schrey: Das Geschichtsbewustsein als Voraussetzung für das Sozialverhalten des Menschen. ZEE jg. 8, 1964. Vgl. ook H. E. Tödt, Ernst Troeltschs Bedeutung für die evangelische. Sozialethik. ZEE ig. 10, 1966; vir Troeltsch ,,bahnt sich die moderne Welt dort an. wo der Mensch merkt, dasz die Grundlagen seines Lebens nicht Schöpfungshaft oder naturhaft vorgegeben sind. sondern vom Menschen selbst gestaltet und verantwortet werden müssen ... Kurzum. es gibt die moderne Welt erst. seitdem die umfassende Gestaltbarkeit des menschlichen Zusammenlebens entdeckt worden ist und das heiszt nicht seit der-Reformation sondern seit der Anfklärung Und diese veränderte Welt erfordert einde neue Ethik." $(31,32)$.

P. Berger beweer (a.w.202): „Van de duizeling van betrekkelijkheid die de historische wetenschap" over het theologische denken heeft gedracht, kan man zeggen dat zij verdiepte wordt in het sociologisch perspectief." 
giese etiek in sy besinning oor die maatskappy, die sosiologie en die historisering, die ,profanisering" van maatskappyvorme waarvan dit spreek, ignoreer ${ }^{\mathrm{s}}$ ).

Die historiese situasie ná die Tweede Wêreldoorlog het die probleem van die ontkoppeling van die teologie (geloof, kerk) van die moderne snelveranderende maatskappy én van die moderne besef van die historiese relatiwiteit van alle institute in ' $n$ nog feller lig geplaas. Die moontlikheid om hierdie drie weer te verenig op die basis van 'n aldrie inklusiewe lewensbeskouing is skynbaar 'n uitgedroomde droom ${ }^{2}$ ). Die sosiologie is altans in die kontemporêre westerse beoefening daarvan, vir so iets nie te vinde nie.

Die verskynsel van die drang na toenemende integrasie van vakwetenskappe ná die tydperk van 'n ekstreem-deurgevoerde verdeling van bevoegdheid beklemtoon ${ }^{10}$ ) die probleem van funksieverlies waarmee die teologie gekonfronteer word. Wat kán die teologie nou eintlik bied?

Dit is sondermeer duidelik dat 'n teologiese sosiale etiek gekonfronteer is met groot probleme, altans as mens as minimum aanvaar dat die christelike etiek darem nie slegs 'n saak is van 'n gevoelsmatige ,gesindheid of blinde' onreflekterende impulsiwiteit nie maar, as verantwoordelike handele, verantwoord is in terme van die grondbegrippe van die christelike geloof, dit wil sê teologies verantwoord is. As die teenstelling tussen die „teologie" as abstrakte teorie en die sogenaamde „praktiese christen-

$\therefore$ Vgl. H. Thielicke, Theologische Ethik II/2, Tübingen 1958, 455: „Es geht mit der Soziologie, die ja ebenso wie die Psychoanalyse fast so etwas wie eine Modewissenschaft geworden ist, ăhnlich wie auf theologischem Gebiet mit der historisch-kritischen Schriftforschung: Nachdem ihre Probleme einmal aufgetreten sind, kann man nicht mehr naiv hinter sie zurück - ganz gleich, ob man die spezifisch soziologischen Lösurgen dieser Probleme anerkennt oder nicht." (kursivering deur myself)

H. M. Kuitert (Sociale Ethiek en Geloof in Jezus Christus, Kampen, 1967, 32v.) beweer: "De tijd ligt voorgoed achter ons dat de christelijke theoloog in z'n pure eentje ethiek bedreef." Die teologie is aangewese op vakwetenskappe, soos bv. die sosiologie en sosiale psigologie. Vgl. ook W. J. M. Jansön, Die Bestaan van God, proefskrif, U.P., 1968, 35.

?. H. Schelsky, Auf der Suche nach Wirklichkeit, Gesammelte Aufsätze, Düsseldorf -Köln 1965, 9 oor ,der Aufschwung der empirischen Sozialforschung nach 1945 in Westsdeutschland mit der Aufnahme der amerikanischen Sozialforschung, insbesondere aber mit den breiten anti-ideologischen Realitäts - und Orientierungsbedürfnissen der deut. schen Gesellschaft nach den Kriege ..."; a.w. 8: ..Ich war der Uberzeugung, dasz die Melodien der Geistes - und Ideengeschichte durchgespielt waren und das abstrakte philosophische, insbesondere das idealistische Denken den Boden einer unmittelbaren und sicheren Welterfrahrung auf den es sich in seiner Entstehung hatte stützen könen. inzwischen unter den Füszen verloren hatte."

10. Sien H. Schelsky, Über die Stabilität van Institutionen, besonders Verfassungen. Kulturanthropologische Gedanken $z u$ einem rechtssoziolische Thema, in: Auf der Suche, $33 \mathrm{v}$. 
dom" van die hand gewys word, begin die verantwoordelikheid vir 'n relevante teologiese sosiale etiek nie eers by die konkrete praktiese daad nie, maar moet die sosiale werklikheid op een of ander wyse van meet af betrek word in die teologiese verstaanshorison. Om dit te doen, en so die konkrete handele van die gemeente te dien, stimuleer en te begelei, is onder andere die taak van 'n wetenskaplike teologiese etiek. Daarmee staan ons voor die probleem van die aard van hierdie wetenskaplikheid en die verband daarvan tot die ander wetenskappe. Slaan die teologiese kategorieë op dieselfde, die één werklikheid, waarvan ook die sosioloog spreek? Is die teologie nie hopeloos uitgelewer aan een van die twee horings van die dilemma nie: om of 'n irrelevante taal te spreek, of om slegs agterna die empiriese analise en filosofiese interpretasies van die sosioloog religieus te beaam? Of is 'n terreinverdeling, wat dan nog op verskillende wyses ingerig kan word, die oplossing, byvoorbeeld dat die taak van die ander denke bestaan in die versameling van "feite", terwyl die „waardering" slegs die prerogatief is van die teoloog?

\section{DIE STANDPUNT VAN KARL BARTH.}

\subsection{Die Saaklikheid van die Teologie.}

In die algemeenste terme verstaan Barth onder die teologie die kritiese selfbesinning van die kerk betreffende haar eiendomlike handele, naamlik haar spreke van God, soos dit geskied in twee voor-wetenkaplike vorme van teologie, naamlik in die geloofs- en lewensgetuienis van die afsonderlike gelowiges, en in die gemeenskaplike handele in die prediking en sakramentsbediening, in die aanbidding en onderrig, in die sending en hulpbetoon. Hierdie opgawe van die teologie val uiteen in drie dissiplines, te wete die bybelse teologie wat gerig is op die beantwoording van die vraag na die oorsprong en begronding van die kerklike verkondiging; die praktiese teologie wat gerig is op die doel daarvan; en die dogmatiese teologie, gerig op die inhoud van die kerklike spreke:

„Dogmatik ist als theologische Disziplin die wissenchaftliche Selbstprüfung der christlichen Kirche hinsichtlich des Inhalts der ihr eigentümlichen Rede von Gott." ${ }^{13}$ ).

Dit gaan in die dogmatiek om die vraag na die waarheidsgehalte van die inhoud van die kerklike spreke; nader, om die soeke na die dogma („das Dogma”) waaronder verstaan word „die Übereinstimmung der kirchlichen Verkündigung mit der in der Heiligen Schrift bezeugten Offenbarung". Die dogmatiek

13. K. Barth, K.D. I/1, 1 vV . 
is "Wissenschaft vom Dogma"14). Die dogmatiek het te doen met die kerklike verkondiging (dus nie met allerlei in die buurt liggende denkprobleme nie; dit is nie 'n afgetrokke sisteem, gnosis of metafisika nie); dit het te doen met die kritiek en korrektuur van die kerklike verkondiging (dus nie met die blote repetering daarvan nie); en - en dit is die beslissende punt ${ }^{15}$ ) (,haben wir es hier mit der entscheidenden Probe zu tun, an der sich ihre Wissenschaftlichkeit immer wieder bewähren musz") - dit vra na die ooreenstemming met die in die Skrif betuigde openbaring. Die onfundeerbare ${ }^{1 i}$ ) en ootmoedige agting op die Skrif is die maatstaf waaraan die saaklikheid, dit is die wetenskaplikheid, van die dogmatiek gemeet word. „In diesem Achten wird der Theologe zum Theologen, in nichts sonst" ${ }^{18}$ ).

Daarmee word die vraag na die verhouding van die dogmatiek en sy hulpdissiplines tot die ander wetenskappe aan die orde gestel:

Die mees in die oog springende feit is dat Barth bewustelik afsien van 'n ensiklopedies-sistematiese inordening van die dogmatiek in 'n wetenskapsgeheel. Dit hou in dat Barth enersyds die verband en die samehang met die ander wetenskappe handhaaf, maar andersyds die afsonderlikheid van die teologie op so 'n wyse beklemtoon dat hy 'n programmatiese sintese of integrasie daarvan met die objekte, die metodes of die resultate van die ander wetenskappe resoluut van die hand wys. Sy afwysing van 'n wetenskapsisteem hang daarmee saam dat hy die afsonderlikheid van die teologie sien as 'n faktiese, onvermydelike noodsaaklikheid wat nie prinsipieel, ,aus allerletzten Gründen"19), geregverdig kan word nie. Inteendeel, prinsipieel kan nie verklaar word waarom alle wetenskappe nie „philosophia christiana", „, in ihrer Spitze Theologie" ${ }^{20}$ ), is nie. Die onsistematiek van die wetenskapsleer van Barth hang wesenlik saam met sy leer van die teologiese nietigheid en ongeldigheid van die sonde ${ }^{21}$ ). „Fakties” - dit beteken die faktisiteit van die sondeval en verlorenheid, van die situasie tussen die tye van skepping en

\footnotetext{
14. $\mathrm{I} / 1,280$.

15. I/1, 300 .

16. I/1, 291 vv.

1i. 1/1, 278: "Wir haben es in keinem Sinn und in keiner Weise zu verantworten, dasz die Bibel wirklich Gottes Wort ist . .. Wir können nicht mehr sagen als dies: die Bibel kann sich in dieser Sache selber verantworten."

19. $I / 1,300$.

19. I/1, 3.

20. $I / 1,5$.

21. Vgi. H. van Oyen. Bemerkungen zu Karl Barths Anthropologie. ZEE jg. $7 / 5$, 301. III $/ 3,327$ vv. oor die aard van die werklikheid van „das Nichtige."
} 
verlossing. „Prinsipieel” - dit beteken die normale maar niebestaande werklikheid van die oerstand en die Ryk van heerlikheid $\left.^{22}\right)$. 'n Sistematies-wetenskapsteoretiese verklaring van die faktum dat die ander wetenskappe nie ,im Raume der Kirche arbeitend, jene Aufgabe: das Reden der Kirche von Gott an ihrem Sein als Kirche zu messen"'s) volvoer nie, sou neerkom op 'n sistematisering en daarom fiksering en normalisering van die onmoontlike en abnormale ${ }^{21}$ ).

Daarom kan Barth enersyds die samehang van die teologie met die ander wetenskappe beklemtoon: die opname van die term „wetenskap" gee eerstens uitdrukking aan die solidariteit van die teologie met die menslikheid en profaniteit van alle wetenskapsbeoefening; tweedens aan die protes teen 'n heidense, kwasie-religieuse verabsolutering van die algemeen-gangbare opvatting van wat "wetenskap" inhou; en derdens dat die teologie die heidendom daarvan nie alte ernstig bejeën nie $\left.{ }^{25}\right)$. Kortom, „weil sie die Kirche bejaht als den verborgenen, aber dennoch und gerade so wirklichen Raum aller menschlichen Erkentnisbemühungen"26).

Andersyds verkry die afsonderlikheid van die teologie vir Barth die rang van ' $n$ beginsel. Dit is weliswaar alleen ' $n$ faktiese, relatiewe noodmaatreël, maar dan terselfdertyd 'n onophefbare faktum. In die beoefening van sy eie saaklikheid het die teologie metodies niks te leer van die ander wetenskappe nie $\left.{ }^{2 \tau}\right)$, en mag dit nie, asof dit 'n ,Zweig der allgemeinen Geisteswissenschaft" is $\left.{ }^{28}\right)$, uitgelewer word aan vreemde kriteria nie. Sy beklemtoning van die metodiese eiesoortigheid van die teologie beteken vir Barth niks anders nie as die totale afwysing van die natuurlike teologie waarmee vir hom alles op die spel staan.

Dit is duidelik dat ten opsigte van die relasie: ander wetenskappe - teologie (teologie hier as die wetenskap van die kennis van God) ' $n$ harmonisasie in enige vorm uitgelsote is. Dit lê nie in sy bedoeling om die teologie te isoleer tot 'n esoteriese aangeleentheid sonder enige kommunikasie met byvoorbeeld die filosofie nie, maar die gesprek, indien enige, sal slegs langs indirekte weg kan geskied. Die resultate van die ander wetenskappe sal teologies slegs relevant kan word via 'n trans-

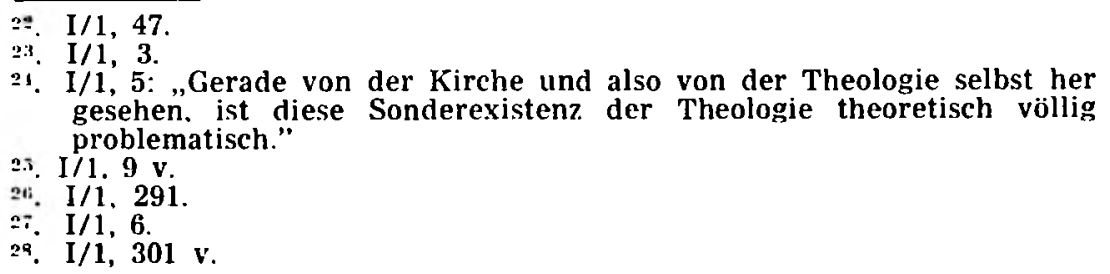

21. I/1, 5: „Gerade von der Kirche und also von der Theologie selbst her gesehen. ist diese Sonderexistenz. der Theologie theoretisch völlig problematisch."

2.. I/1. $9 \mathrm{v}$.

26. $1 / 1,291$.

$\therefore$ I $1 / 1,6$.

29. I/1, $301 \mathrm{v}$. 
ponering in die toonaard van die teologie ${ }^{29}$ ). Dit geld van God as die „voorwerp" van kennis. As ons die blik nou rig op die van God onderskeie werklikheid, tree die probleem van die trefwydte van die teologie in 'n nog skerper en gekompliseerder vorm na vore.

\subsection{Die Teologiese Kennis van die Werklikheid (Skepping):}

Ten opsigte van die kennis van die God onderskeie werklikheid (teologies uitgedruk: die skepping) trek Barth konsekwent dieselfde lyn deur. Hy wys die - op sigself nie onwaarskynlike! - denkbeeld van die hand as sou „zwar die Wirlichkeit Gottes als des Schöpfers ungewisz und also des Beweises oder der Offenbarung bedürftig, die Wirklichkeit des Geschöpfs aber um so gewisser sei, dasz also jene als nichtgegebener, sondern gesuchter, diese aber als der als rocher de bronce vorauszusetzende Faktor in der Schöpfungsfrage zu behandeln sei" ${ }^{30}$ ). Die geloof in die Skepper van hemel en aarde is ' $n$ articulus fidei, en as sodanig nie alleen ' $n$ op die openbaring aangewese belydenis van die werklikheid van God nie, maar dit sluit ook in dat van die "die eigentümliche Wirlichkeit der Welt" eweseer ex revelatione gespreek moet word, met ander woorde „,dasz in der Schöpfungsfrage nicht weiniger, sondern noch viel mehr als nach der Wirklichkeit des Schöpfers auch nach der Wirklichkeit des Geschöpfs gefragt ist" ${ }^{\prime 31}$ ). Dit geld nie slegs van die bewering dat die werklikheid ,is" nie ${ }^{32}$ ) (wat op sigself sou kon inhou dat die funksie van die openbaring slegs bestaan in die garansie van die egtheid van ons natuurlike waarneming), maar ook van ons wete hoe die werklikheid ten diepste is.

Die kritiese grens tussen die teologie as openbaringswetenskap en die ander wetenskappe sny tot in die kennis van hierdie wêreld in. Daarom verset Barth hom skerp teen enige greep na 'n alles-inklusiewe, kosmiese totaalsisteem via 'n sintese van teologie met ander wetenskappe („Weltanschauung"). Die veld van die geskapene omvat „die hemel en die aarde”, dit wil sê die ganse kosmos, en die mens is 'n deel van die skepping, nie die hele skepping nie. Daarom waarsku Barth teen 'n isolering van

29. Vgl. I/1, 4: „Die Leistung des Philosophen, Historiker usw. kann faktisch für das hier vorliegende Problem immer nur indirekt, mittelst einer bestimmten Interpretation bedeu tsam werden. Direkt übernommen haben Philosophie. Geschichtswissenschaft. Psychologie usw . . . faktisch noch nie etwas anderem als der Vermehrung der Selbstentfremdung der Kirche, der Entartung und Verwüstung ihrer Rede von Gott gedient."

3i. III $/ 1,4$.

31. III $/ 1,4$

$\because$ III $/ 1,395$ v. 
die mens van die kosmos wat hom omring":). En tog kan die christelike teologie, in navolging van die Skrif, nie sy tema sien in die synstotaliteit nie. Die Woord van God bied geen „Ontologie des geschaffenen Alls" nie, maar ,zweifellos eine ontologie des Menschen" ${ }^{34}$ ). Die motief vir sy afwysing van 'n teologiese kosmologie is die bewaring van die suiwerheid van die teologie as skrifgebonde denke, wie se taak slegs daarin kan bestaan om „das biblische Zeugnis von der Schöpfung immer vorbehaltloser und vollständiger aufzufassen und immer getreuer und genauer wiederzugeben ${ }^{35}$ ).

Die teologie kan geen wêreldbeskouing word nie. Dit kan op geeneen steun en vir geeneen borg staan nie. Barth ontken nie die feitelikheid van 'n kontaminasie van die teologie met heersende en telkens wisselende wêreldbeelde nie, maar dit mag slegs die karakter dra van 'n terloopse, onprinsipiële, vrye en eklektiese gebruikmaking van die begrips- en voorstellingsmateriaal van die wêreldbeskouing - 'n losse, onwillekeurige verbinding waarin die geloof altyd die karakter van 'n corpus alienum in die geheel sal hê. Waar gesoek word na 'n opsetlike hybridisering van die teologie aan 'n bepaalde wêreldbeskouing, begin die afval van die geloof. Die teologie kan hom ook nie direk met die wêreldbeskouings „auseinandersetzen” nie, „d.h. sie kann ihre Aufgabe nicht darin sehen, sich partiell zustimmend zu ihnen und partiell ablehnend gegen sie zu stellen" ${ }^{36}$ ). Enersyds selfs geen weerspreking daarvan nie, andersyds juis dáárin 'n fundamentele weerspreking. „Sie führt das Gespräch mit den Weltanschauungen in der Weise, dasz sie ihre eigene Erkenntnis ihres eigenen Gegenstandes in der ihr eigenen Begründung und Folgerichtigkeit nicht besserwissend, aber anderswissend, und ihr anderes Wissen nicht verleugnend, sondern entfaltend neben und gegen jene stellt"'si). Die wins wat vir die teologie uit hierdie ontmoeting te voorskyn kom, is geen saaklike, direkte kennisverdieping nie, maar kan slegs bestaan in die loutering en presisering van sy verhouding ten opsigte van sy eie tema; vir die wêreldbeskouings bestaan die wins daaruit dat die verteenwoordigers daarvan, deurdat hulle die getuienis van God die Skepper te hore kom, opmerksaam gemaak word op die fundamentele agterhaaldheid van hul eie, deur beperkte vraagstellinge gebonde sisteme en uitgenooi word tot die „verbetering” en ten slotte die ontbinding daarvan ${ }^{33}$ ).

\footnotetext{
$\therefore$. III /1, 395 v.

$\because$ i. III $/ 2,1$ vv.

35 III $/ 1,314$.

si. Ibid.

37. III/1, 394.

39. III/1, 394.
} 
Korrelatief aan sy afwysing van die pseudo-teologiese deureenhaling van wat kategoriaal verskillend is, is Barth se uitgesproke waardering van die eksakte wetenskappe en konstateer hy 'n metodiese verwantskap van die teologie met die ,in der reinen Verknüpfung von Wahrnehmung und Denken sich konstituierenden exakten Wissenschaft"39). Ook die korrekte eksakte wetenskap sluit geen wêreldbeskouing in nie; dit is suiwer (,reine Wissenschaft"), eerstens in sy onderskeiding van die teologie (dit het te doene met fenomene van die skepping, nie met die skepping as sodanig nie), en tweedens van die pseudo-teologiese konstruksie van kosmiese sisteme. Ook die eksakte wetenskap bestudeer die kosmos slegs in antroposentriese dimensie, dit wil sê binne die begrensing van die menslike waarnemingsen denkvermoëns. Ook die eksakte wetenskap hou rekening met die bestaan van twee fundamenteel onderskeie bereike. Wat teologies die onderskeid tussen hemel en aarde is, is vir die eksakte wetenskap die grens tussen die bereik van die menslik waarneembare en denkbare, en die bereik van die menslik niedenkbare „den sie zwar als reine Wissenschaft nicht leugnen kann, den sie, so gewisz er des ersten Bereiches grenzen bildet, mindestens gelten lassen wird, vor dem sie auch Halt nachen, den zu betreten sie nicht versuchen wird, von dem sie als reine Wissenschaft nur ehrerbietig schweigen kann"10). Barth sien die moontlikheid van 'n vreedsame naasmekaarbestaan van die teologie met hierdie wetenskap op die basis van 'n strikte eerbiediging van grense, met aan weerskante van die kritiese grens, 'n eie, vrye ruimte vir elk.

Waarteen Barth veg, is die verheffing van die onvermydelike feitelikheid van die verknoping van die teologie met 'n stel min of meer algemeen aanvaarde oortuigings aangaande die samehang van alles wat is, tot die rang van 'n prinsipiële kontaminasie van die teologie, waarby die nie-teologiese oortuigings die rol van 'n kriterium in die teologie gaan speel. Of hierdie „Vorverstăndnis" eksistensialisties en of dit kosmologies, of dit rasioneelwetenskaplik en of dit irrasioneel-mitologies, of dit teoretiesbeskoulik en of dit prakties-konkreet, of dit religieus en of dit natuurwetenskaplik of polities van aard is, is 'n sekondêre vraag.

Met hierdie terreinafbakening is natuurlik nog nie alles gesê nie, en die beswaar sou aangevoer kon word dat ten opsigte van die antropologie, waar dit tog juis om gaan, so 'n maklike onderskeiding nie gemaak kan word nie. Hier het die teologie immers

39. III/2, 12 .

40. III $/ 2,13$. 
nie soseer met die natuurwetenskappe nie as met die geesteswetenskappe te doen, wat die verhouding tog veel gekompliseerder maak. Nou is dit opvallend dat Barth die wetenskapsideaal van die eksakte natuurwetenskap ekstrapoleer tot die wetenskapsideaal überhaupt. Op die analogie met die teologie is reeds gewys. Die teologiese antropologie beperk hom tot die ontvouing van die menslike wese vir sover dit positief deur die Woord van God belig word ${ }^{41}$. Die nie-teologiese antropologie word in twee kategorieë ingedeel, naamlik die spekulatiewe en die eksakte ${ }^{12}$ ). Die spekulatiewe denke word - of dit nou uitgaan van intuitiewe of van eksakte kennisvorming (in laasgenoemde geval oorskry dit die grense van die eksakte wetenskap deur die hypostasering tot aksiomatiese beginsels van wat slegs hypoteses kan wees) - volledig gediskwalifiseer as die vyand wat geen bestaansreg het nie, „dem man anders als mit der Entgegenstellung des christlichen Bekenntnisses nicht begegnen kann."

Die tweede tipe nie-teologiese antropologie is die van die eksakte wetenskaplikheid, waarmee bedoel word besinning sonder die pretensie om deur te dring tot die diepste wese en werklikheid van die mens, wetenskaplikheid waarvan die kompetensie beperk bly tot die veld van die fenomene ${ }^{43}$ ), tot die blootlegging van die menslike "Möglichkeit", tot die benadering van die "Schattenmenschen", tot die aanduiding van voorlopige gesigspunte; wetenskap waarvan die resultate slegs opgevat kan word as relatiewe hypoteses, as „so etwas wie ein Momentbild für heute", as „die Ergebnisse ihrer bisherigen Forschung zusammenfassende und formulierende Spitzensătze", as "die Wegweiser für den künftigen Fortgang ihrer Forschung"").

Binne hierdie begrensing gee Barth aan hierdie wetenskappe vrye speelruimte, word dit gehonoreer as behorende tot die vanselfsprekende menslikhede soos eet en drink, slaap, en alle ander menslike aktiwiteit, tegniek en prestasie, ,in denen hinsichtlich des Hörens oder Nichthörens des Wortes Gottes an sich nichts präjudiziert wird, die erst durch ihren Charakter als Lebensakte dieses und dieses mit seiner besonderen Lebensrichtung und Absict zu Akten des Gehorsams oder des Ungehorsams werden, die aber auch als Akte eines ungehorsamen Menschen, auch in Zusammenhang seiner verkehrten Absicht und Lebensrichtung in sich gut sind und bleiden"'5).

\footnotetext{
11. III $/ 2,20 \mathrm{vv}$.

12. III $/ 2,23$ vv.

1?. III $/ 2,236$ vv.

11 III $/ 2,25$.

4.). III $/ 2,27$.
} 
'n Grens word getrek tussen teologie en hierdie wetenskap, maar dit is geen antitetiese afgrensing nie. Dit is duidelik dat Barth ernstig worstel om die moontlikhede en voorwaardes vir 'n gesprek tussen teologie en die nie-teologiese wetenskap te vind en om ín die handhawing van die suiwerheid van die teologie, nie te swig voor die gevaarlike dwaling waar teologie en ander wetenskap slegs in betrekkinglose isolasie náás of téén mekaar beoefen word nie. 'n Moontlikheid van koëksistensie wat van meet af uitgeslote is, is die konstruksie van 'n direkte aansluiting van die teologie aan en die kompletering van die teologie deur die ander wetenskap, die oprigting van die teologie op die onderbou van die ander wetenskap ${ }^{\$ 6}$ ). Barth sien daarin die analogia entis en die natuurlike teologie. Vanuit die fenomene kan nie gekonkludeer word op die werklikheid nie. Die fenomene is nie die werklikheid nie, en suggereer ook nie die werklikheid nie. Op sigself is die fenomene veelduidig en neutraal. Tog gee die woord "Möglichkeit" uitdrukking aan méér as teologiese indifferentisme, so ook die terme „Fähigkeit”, „Symptome” en "Potentialität". Maar (en dit is die belangrike punt) hierdie kwalifikasie geskied slegs vanuit die teologiese kennis van die „Wirklichkeit". Die standpunt van Barth beteken dus méér as net die terugdringing van die ander wetenskappe tot die veld van die verskynsels. Dit beteken óók dat die teologie ten diepste gemaak word tot veronderstelling van dis ju:ste funksionering van die ander wetenskappe. „Moontlikheid" en „werklikheid” is weliswaar korrelatiewe begrippe, en Barth wil hierdie betrokkenheid eerbiedig, maar die twee groothede lê nie liniêr op dieselfde vlak nie, en die spreke oor beide is kategoriaal verskillend, sodat die twee wyses van spreek nie in een koördinatestelsel gevang kan word nie.

Daarom beteken die onderstelling van die teologie nie direkte onderrig aan die ander wetenskappe nie; „Gottes Wort und Offenbarung ist nicht die Quelle, aus der diese Wissenschaft ... ihre Kunde vom Menschen schöpft. Sie ist in allen ihren Gestalten die allgemeine Wissenschaf des sich selbst über sich selbst belehrenden Menschen" ${ }^{*}$ ). Vanuit die teologie word nie 'n prejudisering van die profaanwetenskaplike resultate voorsien nie - wel die aanwysing van die konteks, die horison, waarbinne die resultate geplaas word. Die begrensing is beperkend èn singewend, krities èn beamend. Dit is nie 'n diskwalifikasie van die menslike rede nie, maar 'n kwalifikasie daarvan; 'n aanwysing van die betreklikheid daarvan èn die uiteindelike betrokkenheid

4i. Vgl. O. Weber, Grundlagen der Dogmatiek I, 592 vv.

47. III $/ 2,241$. 
daarvan op die openbaring. Só is dit 'n poging tot die egte bevryding van albei tot eie saaklikheid.

Behalwe sy afgrensing teen die valse binding van die ander wetenskappe aan die teologie waarby van eersgenoemde verlang word om hul bevindinge "uit die Bybel te skep," is dit ook opvallend op watter vlak die twee benaderinge van die werklikheid mekaar raak. Dit is die kontak (gesprek)! tussen twee soorte wetenskap, dus nie tussen wetenskap (byvoorbeeld die sosiale wetenskap) en 'n soort intuïtiewe, ongekontroleerde en onkontroleerbare, subjektiewe "gesindheid" van die hart nie. Barth sien die kontak as ' $n$ wisselwerking tussen teologie as die wetenskap van saaklik die Skrif naspreek en vertolk, en die dissiplines wat die fenomene eksak bestudeer.

Bogenoemde uiteensettinge kry by Barth konkrete vulling veral in sy gesprek met die filosofiese antropologie $\left.{ }^{4 i} a\right)$. Tot 'n ware gesprek met byvoorbeeld die natuurwetenskappe het Barth nooit gekom nie (hoogtens „dankbare Probleme” vir toekomstige arbeiders gesien ${ }^{48}$ ) - iets waarteen kritiek gerig kan word en gerig is ${ }^{49}$ ). Ofskoon Barth hom nie breed en gedetailleerd besighou met die sosiologie nie, is die algemene rigting wat hy aandui, duidelik en bied dit belangrike gesigspunte ${ }^{50}$ ), wat ons voorlopig só kan saamvat: 'n strenge vashouding aan die tema van die teologie, gepaard met 'n onbevange openheid teenoor die sosiologie. Die teologie sal nie die resultate van sosiologiese navorsing prejudiseer nie (vandaar sy afwysing van ,eine an sich und als solche heilige Soziologie") ${ }^{51}$ ) - met die voorbehoud dat die teologie afwysend sal staan teenoor die sosiologisme, in watter vorm ookal.

\subsection{Die Teologiese Etiek:}

Tot die samelewing van die mense behoort nie slegs die feitelike gegewenhede van bepaalde strukture nie, maar ook die voortgaande herstrukturering van die samelewing en sy institute aan die hand van bepaalde norme, waardes, beginsels, of hoe mens dit ook al wil noem. Ook hier stuit teologie en sosiologie op mekaar. Ook hier wil ons nie probeer om die probleem as sodanig te analiseer nie. Ons wil slegs, as kontrole én aanvulling van die voorafgaande, nagaan hoe Barth die aangetoonde lyne deurtrek met betrekking tot die teologiese etiek, en ons

\footnotetext{
tia. III/2, paragraaf 44.2 .

48. Voorwoord tot III/1.

40. Kritiek word bv. ook uitgeoefen deur 'n welwillende teoloog soos dr. J. M. de Jong, in: Geloof en Natuurwetenschap, Deel 1, Den Haag 1966. $60 \mathrm{vv}$.

50. Vgl. H. de Loor, Hoekendijk en Verder . . ., Amsterdam 1966, III, v. 51. IV $/ 3,846$.
} 
neem as uitgangspunt daartoe die twee betekenisse wat hy heg aan die woord etiek: eerstens is daar die met die griekse woord ethos (letterlik: woning, stal, dan: gewoonte) korresponderende etiek as „Wissenschaft, Kunde, Lehre von den menschlichen Handlungsweisen, von den Stetigkeiten, von den Gesetzen menschlichen Handelns" ${ }^{2}$ ); tweedens spreek hy van etiek in die egte en eintlike sin van die woord: "Die ethische Frage ist die Frage nach dem Grunde und der Möglichkeit dessen, dasz es in der Menge und Vielfältigkeit der menschlichen Handlungen auch Handlungsweisen, d.h. gewisse Stetigkeiten, gewisse Gesetze, Regeln, Gewohnheiten, Kontinuitäten gibt. Sie ist die Frage nach der Richtigkeit dieser Stetigkeiten, nach der Angemessenheit jener Gesetze. Sie ist die Frage nach der Würde, die irgend einer Handlung den Anspruch gibt, der einmalige Ausdruck einer Handlungsweise, die Erfüllung eines Gesetzes zu sein: den Anspruch, sich wiederholen zu dürfen und kraft ihrer Regel-Mäszigkeit den Handlungen Anderer als Vorbild zu dienen. Welches ist die wirkliche, die echte Kontinuität in all den angeblichen Kontinuitäten menschlichen Handelns? Was ist das Gültige in und über all den geltenden Gesetzen? Welches ist das Gute in und über allem angeblich Guten des menschlichen Handelns? Das ist - relativ allgemein gesagt-die ethische Frage und ihre Beantwortung ist - in derselben relativen Allgemeinheit gesagt - das, was man „Etik" zu nennen pflegt ${ }^{53}$ ).

Teologies gesproke is etiek die vraag na die wil van God as gebod $^{54}$ ) 'n vraag wat slegs ter sprake kom in onlosmaaklike samehang met die wil van God in die uitvoering van sy verbondsplan, dit wil sê met die Christologie en die daaromheen staande temas van skepping, versoening en verlossing. Daarom is die etiek ' $n$ integrale bestanddeel van die dogmatiek, met as taak die eksplisering en rekapitulering ${ }^{55}$ ) van die dogmatiese grondbegrippe in hul etiese, eksistensiële gerigtheid ${ }^{56}$ ). 'n Skeiding van dogmatiek en etiek anders as op bloot tegniese, praktiese gronde, is volkome uitgeslote. Die geskiedenis van die verselfstandiging van teologiese etiek vertoon die beeld van 'n endemiese isolering en abstrahering van die handelende mens en sy „norme van God, die uitlewering van die „teologiese" etiek aan 'n ,,algemene" antropologie en ontologie, en uiteindelik die verandering van die dogmatiek self in so 'n algemene antropologie. Die skeiding lei tot en vloei voort uit 'n fatale verandering van blikrigting in die teologie en 'n fatale verwisseling van subjekte,

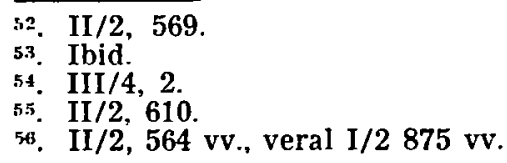


naamlik van God en mens. Dat die etiek 'n aspek is van die dog. matiek is slegs die konsekwente handhawing daarvan dat die "Theologie . . . in allen ihren Sparten Darstellung der Wirklichkeit des sich an den Menschen richtenden und ihn zurecht richtenden Wortes Gottes(ist)" ${ }^{57}$ ). Die dogmatiek is in al sy dele etiek, en al is dit so dat daar in die dogmatiek 'n besondere gebied is, (gekarakteriseer deur die trefwoorde "wet”, ,sonde”, „heiliging", ens.) waarin die etiese vrae direk $€$ n uitdruklik ter sprake kom, beteken dit nie dat daar dogmatiese gebiede is wat eties irrelevant is nie. Die eenheid van dogmatiek en etiek sluit egter nie uit nie dat dogmatiek primêr die vraag is na Gods Woord en slegs in ondergeskikte en onselfstandige sin die vraag is na die christelike lewe ${ }^{58}$ ). So verkry die etiek die karakter van 'n teologiese hulpwetenskap.

Dit is duidelik dat Barth ook in die etiek konsekwent vashou aan die Openbaring as die teo.ogiese tema, waarmee ons weer eens gekonfronteer word met die vraag na die relasie van die teologiese tot die nie-teologiese, nou toegespits op die kennis van die kontinuitteite in die menslike gedraginge. Die sosiologic kom hier direk in sig. Dit gaan om die verhouding van die teologiese tot die nie-teologiese omgang met die menslike gedrag (wat in hierdie verband beteken die tussenmenslike, maatskaplike gedrag) sowel ten opsigte van die aanwysing/ontdekking van gegewe, faktiese reël-/wetmatighede van die tussenmenslike aksies en reaksies, en ten opsigte van die beoordeling van die wetmatighede, dit wil sê die vraag na die dieper reg daarvan.

2.3.1. Om met die „egte" etiek te begin: Die christelike teologie staan in presies dieselfde verhouding tot ander etieke as tot ander teologieë, 'n verhouding wat Barth illustreer met verwysing na die intog van die kinders van Israel in die deur ander volkere besette Palestina ${ }^{55}$ ): geen aanknoping by, positiewe erkenning of voortsetting van, uitbouing of verryking deur die ander nie. Dit is die handhawing daarvan dat ,alle ethische Wahrheit beschlossen ist in dem Gebot der Gnade Gottes";:) en beteken vir Barth die afwysing van drie houdinge: eerstens die apologetiese houding. „Apologetik wäre in diesem Fall der Versuch einer Begründung und Rechtfertigung der theologischetischen Fragestellung im Rahmen und auf Grund der Voraussetzungen und Methoden eines nichttheologischen, eines allgemein menschlichen Denkens und Redens" ${ }^{61}$ ). Tweedens beteken

\footnotetext{
$\therefore$ I/2. 884 .

ㅅ. $1 / 2.888$

i. II/2, 575 .

คก. II/2, 584 .

(i). II/2, $577 \mathrm{vV}$
} 
dit die afwysing van 'n standpunt van isolering en beskeie terreinverdeling, van 'n dubbele vraagstelling (bv. 'n ,teologiese" en 'n ,filosofiese") wat mekaar wedersyds begrens maar nic ophef nie. Bedenklik is hierdie vorm van diastase, waar die teologie teruggedruk word tot 'n obskure terrein en die selfstandigheid van die rede, die ervaring, ensovoorts geproklameer word, en Barth vra: „Gibt es auszer und neben dem Reich Jesu Christi auch noch irgendwelche andere respektable Reiche?"'62). Die differensiëring ten opsigte van 'n etiek wat voorgee om te weet van goed en kwaad en wat terselfdertyd die teologiese etiek ontbeer of verloën, kan alleen 'n ,endgültige Distanzierung" wees. Die teologiese etiek „hätte dann davon auszugehen, dasz alle ethische Wahrheit beschlossen ist in dem Gebot dor Gnade Gottes: ganz gleichgültig, ob darunter die vernünftige oder die geschichtliche, die profane oder die religiöse, die kirchliche oder die allgemein gesellschaftliche ethische Warheit verstanden sein soll". Eers in die konteks van die Openbaring kan die rede, ervaring, ensovoorts in die regte lig gesien word. Daarom spreek die teologiese etiek algemeenverbindelik, en neem dit die legitieme probleme van alle ander etiek ,nach daren Prüfung im Lichte ihres eigenen überlegenen Prinzips" op. In soverre staan dit nie negatief nie maar komprehensief teenoor die ander ,aber eben weil komprehensiv, darum auch grundsätzlich kritisch und gerade nicht schiedlich-friedlich!". Vir sover die ander etiek nie (wil) weet van sy oorsprong en grond in Gods gebod nie en ander outonome en heteronome teë-instansies oprig, kan die verhouding alleen eksklusief wees. Derdens wys Barth die roomskatolieke harmonisasie van die hand ${ }^{(33}$ ), waar die uitlewering van die teologie aan 'n vreemde „Prinzipienlehre” en die beknotting daarvan tot 'n klein aspek van die sedelikheid netjies verhul word. Die sameordening van moraalfilosofie en moraalteologie berus op die synsmetafisiese harmonie van natuur en bonatuur, rede en openbaring, mens en God. Barth noem hierdie oplossing klassiek en meesterlik in vergelyking met die dilettantisme waarmee die neoprotestantisme dieselfde weg bewandel. „Die römischtheologsche Ethik ist insofern die weiseste alle Vermittlungen, als sie geradezu in ihrem Ansatz, in ihrem Verständnis von Gnade, Offenbarung und Gott selbst apologetisch ist, d.h. Begründung und Rechtfertigung der christlichen Position vor dem Forum des allgemein menschlichen und also die fatale Angleichung des Christlichen an das Menschliche vollzieht" $\left.{ }^{\prime \prime}\right)$. Die teologiese etiek kan nie beweeg op die neutrale terrein van

62. II/2, 584 .

6.3. II $/ 2,586$ vv.

64. II $/ 2,593$. 
'n algemene behandeling van menslike handele, geabstraheer var Gods gebod nie. Die probleem van die menslike handele, wat die teologie gemeenskaplik het met die filosofie, die politiek, die pedagogiek, ensovoorts, staan vir die teologie van meet af in die konteks van die goddelike gebod in Christus waaroor ons deur die Heilige Skrif onderrig word en die menslike gehoorsaamheid of ongehoorsaamheid aan Hom. Die teologie kan nie „maak asof" dit nie weet van die beslissing oor goed en kwaad wat, eens en vir altyd, gegee is in die raad van God, deur die kruis en die opstanding van Jesus Christus nie. „Sie ist, wie die Theologie überhaupt, nicht damit beschäftigt, den Dingen auf den Grund zu kommen. Sie kann nur den Grund bezeugen, den alle Dinge tatsächlich haben und der sich als solcher tatsächlich offenbart hat"'65).

Dit beteken nie dat Barth summier die bestaansreg van 'n nie-teologiese etiek naas die teologiese etiek verwerp nie. So 'n etiek is moontlik, maar dan as etiek wat dieselfde uitgangspunt, grondslag en doel het; 'n etiek wat, sonder om hom skuldig te maak aan die apotheose van die mens as prinsiep van die goeie, indirek óók weet van die gehoorsaamheid, indirek óók die mens wegroep van homself, indirek óók oproep tot lofprysing van die genade van Jesus Christus. Hierdie "christelike" etiek is nie 'n saak van eksplisiete, wetenskaplike fundering nie, maar dit staan as't ware tussen die teologie en die christelike lewe self. As dit wetenskaplik en fundamenteel wil spreek, dan sou dit self teologiese etiek moes word. Barth verwys hier na die lewenswerk van $H$. Pestalozzi, na die romans van Jeremias Gotthelf, $H$. de Balzac, ensovoorts; so 'n etiek kan uitkristaliseer in bepaalde politieke en sosiale denkbeelde en in die ontwerpe van filosofiese etici. Origens beperk hy die moontlikheid daarvan nie tot die historiese gebied van die christendom nie. Barth spreek hier heel ruim en los van ,christelik" as dit wat ooreenstem met wat goed christelik-teologies is. „Der Prüfstein aller solchen nicht theologischen Ethik wird aber doch gerade darin bestehen, ob und in welchem Masz sie es erträgt, sich nach ihren Grundsätzen fragen zu lassen, ob und in welchem Masz sich ihre unausgesprochene Voraussetzengen, würden sie ausgesprochen, als mit denen der theologischen Ethik identisch erweisen würden"66). Danksy die geduld en wysheid van God en die inkonsekwentheid van die mense is dit moontlik dat allerlei christelike insigte en

6.5. II $/ 2,595$.

66. II/2, 602 . 
konsekwensies kan voorkom, selfs by weinig christelike voorveronderstellinge. Hierdie komprehensief-kritiese benadering van die nie-teologiese etiek, waarby ook die ruimte inbegrepe is om positief te waardeer, word deur Barth kernagtig as volg saamgevat: „Das ändert aber wieder nichts daran, das bestätigt vielmehr, dasz in thesi, grundsätlich . . . alle richtige Ethik nur christeliche Ethik sein kann und dasz christeliche Ethik, wenn sie wissenschaftiich reden will, von theologischer Ethik sich nich unterscheiden kann. Sodasz wir unsere Frage, letzlich, streng genommen, doch dahin beantworten müssen, dasz es in wissenschaftlicher Gestalt nur eine, die theologische Ethik gibt" ${ }^{67}$ ). Wat betref die konfrontasie met die ander etiek vir sover dit leer van die regte handele wil wees, volstaan ons met bogenoemde opmerkinge omdat dit die rigting aandui waarin, op die standpunt van Barth, die rol van die teologie gesoek moet word ten opsigte van die genormeerde begeleiding van maatskaplike prosesse.

2.3.2. Vervolgens vestig ons die aandag op wat Barth ter sprake bring onder "etiek" in die letterlike, maar oneintlike sin van die woord $\left.{ }^{6 s}\right)$, naamlik etiek as die kennis van die reëlmatighede van die menslike handelswyse. Dit is 'n vraag wat volgens Barth in baie wetenskappe aan die orde is, byvoorbeeld die psigologie, die moraalstatistiek, die sedekunde, en in wyere omvang, die kultuurmorfologie. So vra die positiewe regswetenskap na die gevestigde regspatrone van die staatsgemeenskappe. Die geskiedsfilosofie vra na die konstante patrone wat afgeteken word in die veranderinge en ontvouing van die historiese proses. Barth staan oop vir die resultate van hierdie vorme van navorsing - met die voorbehoud dat feit onderskei word van reg! Hy ontken nie die positiewe reg nie, wel die regspositivisme of die vereenselwiging van die moraliteit met die positiewe wette van die staat; hy ontken nie so iets as 'n „Natuurgesetz (ook in die sedelike handele) nie, wel die identifisering daarvan met die ware sedewet; hy ontken nie dat 'n geskiedsfilosofie moontlik sekere wetmatighede in historiese ontwikkelinge kan aantoon nie, (Barth verwys hier selfs na die geskiedsvisie van die Marxisme en die duitse nasionaal-sosialisme;) maar voeg onmiddellik daaraan toe: ,so ist doch offenbar die Feststellung solcher Gesetze eines, ihre so stürmisch geforderte aktive Bejahung aber

67. II/2, 603 .

68. II/2, 569 vv. 
ein anderes"(i:). Die teologies-etiese vraag (etiek in die egte sin van die woord) val nie saam met die psigologiese, historiesmorfologies, polities-juridiese of geskiedsfilosofiese vraag nie die teologiese-etiek vra krities na die egtheid, die waardigheid, die geidigheid van alle gegewe wetmatighede om as verpligtende instansies te funksioneer en die etiek kan dit alleen doen aan die hand van die één Kriterium wat dit maak tot christelik-teologiese etiek. Ons bevind ons hier duidelik in die sfeer van die fenomene van sy antropologie.

Die uiteensettinge wat ons in 2.2 en 2.3 weergegee het, verkry 'n besonder interessante en insiggewende toespitsing in die vlymskerp kritiek van Barth op die ordinologie van E. Brunner, P. Althaus en ook D. Bonhoeffer').

Die kern van sy kritiek is juis dat die ordeningsleer van genoemde teoloë die resultaat is van 'n onkritiese vermenging van 'n teologie van die skepping met die ,allgemeine ... Wahrheit gewisser Lebens - und Daseinsgesetze, von denen die sogenannte "Wirklichkeit" in der Tat gewisse mehr oder weniger sichere und klare Kunde gibt und die dann als solche in der Tat von Jedermann mit mehr oder weniger Sicherkeit und Klarkeit erkannt werden könne"'). Die vermenging het betrek. king op sowel die ondcrskeid wese-fenomeen as op die onderskeid gebod-fenomeen. Brunner en Althaus byvoorbeeld het op 'n swak teo'ogiese en naief sosiologie wyse 'n paar strukture in die samelewing ,ontdek"3) en daaraan op teologiese-ongegronde wyse gebodskarakter toegeken.

$\therefore$. II/2, 570. Ook in sy leer van die voorsienighe:d kom sy kritiese opvatting t.o.v. die ,.Weltan chauungen" na vore. " $n$ "Weltanschauung" as ' $n$ bepaalde geskiedsvisie is onvermydelik en as sodanig ook nie verbode nie, - dit kan geld van individue, van gemeenskappe (bv. die kerk of die volk,) of 'n groep in ' $n$ volk of van die proses waarin die heelal betrokke is. Maar: die geloof in God lê hom nooit dáárop vas asof dii God is nie. Die gelowige kan so iets selfs gebruik as instrument. as arbeidshipotese, maar hy is vry daarteenoor (ook vol humor!) en hy glo nie daaraan nie, vgl. III/3, 21 vv. 64 vv. Sy kriteik op die nasionaalsosialistiese ideologie lê hier. In IV $/ 3,293$ vv., kom hy weer terug op hierdie tema, hierdie keer weer geweldig skerp in sy kritiek vanuit die gesigcpunt: ,Jesus ist Sieger!"

1. III/4. paragraaf 52.1 (,.Das Problem der spcziellen Fthik") en 52.2 (,Gott der Schöpfer als Gebieter").

2. III $/ 4,41$.

3. .Was ich aber nicht verstehe. ist dies woherund wie Brunner um diese ,Ordnungen' $\mathrm{zu}$ wissen meint", III/4, 21. 


\section{SAMEVATTENDE GEVOLGTREKKINGE:}

Hier volg nou 'n aantal stellinge, waarvan sommige eenvoudig samevattinge is van wat uitvoeriger in die voorafgaande behandel word, terwyl ander 'n stap verder gaan en bepaalde implikasies daarvan aanraak.

\section{Cor die teologie:}

Barth benader die verhouding tussen teologie en sosiologie nie vanuit 'n algemene wetenskapsteorie wat albei oorkoepel nie, maar vanuit die saaklikheid en metodiek van die teologie self.

\section{Die objek van die teologie:}

Die saaklikheid van die teologie (nader: die dogmatiek) bestaan primêr uit die kritiese selfbesinning van die kerk ten aansien van haar spreke van God as „objek". D:e saaklikheid van die teologie sluit in dat die teologia handel oor die dieptedimensie, die wese, van die sosiale werklikheid.

Dit sluit ook in dat die teologie handel oor die goddelike gebod vir sover dit betrekking het op die tussenmenslike verhoudinge.

\section{Die grens van die teologie:}

3.1. Die kriterium aan die hand waarvan die teoloog sy teologie bedryf, is die Heilige Skrif alleen.

3.2. Die teologie is slegs gebonde aan sy eie kriterium en metodiek. Dit kan slegs vrae stel en antwoorde gee op vrae wat gestel is in terme van die teologiese referensie-kader, en die teoloog mag hom nie laat verlei om uitsprake te doen oor die sosiale werklikheid wat hy nie in terme van sy eie kriterium kan verifieer nie.

\section{Teologie en ideologie:}

Die teologie mag nooit die rustige en gewillige vennoot word in 'n wêreldbeskouing (en lewensopvatting) of (sosiologies gesproke) 'n ideologie ${ }^{2}$ ) nie. Dit bly 'n vreemde voorwerp daarin.

\section{Oor die sosiologie:}

Oor die saaklikheid en die metodiek van die sosiologie as sodanig laat Barth hom nie direk uit nie.

Uit sy benadering vloei egter wel die volgende konsekwensies voort:

\footnotetext{
Net soos ,.sekularisasie" is ook die woord ..ideologie" oorbelas. Volgens Beerling (Wijsgerig-sociologische verkenningen II, Arnkem 1965, 26) het die Franse sosioloog Gurvitch 'n lys van 13 betekenisse saamgestel! In aansluiting by Beerling in sy studie (a.w. 27, 30, 53) bedoel ons met ideologie: 'n kollektiewe wêreldbeskoulike interpretasiesisteem, êrens tussen mite en wetenskap in, van aktiverende waarde-oordele aangaande die werklikheid, met 'n beroep waarop 'n bepaalde sosiale sisteem gelegitimeer of nagestreef word. Sien André Dumas, Die Funktion der Ideologie, in: Die Kirche als Faktor einer kommerden Weltgemeinschaft, $84 \mathrm{vv}$.
} 
6. Barth hou prakties nie daarmee rekening dat die sosiologie oor God, oor die wese van die tussen-menslike verhoudinge, of oor die gebod van God kan spreek nie. Dan sou dit teologie word.

7. Die sosiologie is 'n empiriese wetenskap wat die sosiale fenomene bedryf, wat bepaalde hipoteses met beperkte, voorlopige betekenis daaroor opstel, maar wat halt maak voor die bo-empiriese.

8. Die sosiologie mag sy grense nie spekulatief oorskry deur aandeel te neem aan die konstruksie van lewensbeskouinge of ideologieë nie. Dit sal krities wees ten aansien van sulke konstruksies.

\section{Oor die wisselwerking tussen teologie en sosiologie:}

By Barth staan die deur wyd oop vir 'n verkeer tussen teologie en sosiologie. Sy standpunt bied die moontlikheid vir die sosiale etiek om vatplek te kry aan die snelle beweeglikheid van die moderne samelewing. In die KD gaan dit lank nie meer (en hoe later hoe minder) om pure kontaklose vertikalisme.

10. Teologie en sosiologie is korrelatief op mekaar betrokke en op mekaar aangewese:

101.1. Die grens tussen beide moet eerbiedig word: die een moet nie die ander oorheers deur byvoorbeeld bloot pragmatiese gebruik daarvan te maak as ,hulpwetenskap nie, nie die ander se rol probeer oorneem nie, nie met die ander vermeng word nie, geen teososiologie of sosioteologie word nie.

10.2. Die korrelasie beteken nie direkte, liniêre aansluiting of harmonisasie nie. Die een is die liniêr - eenvoudig die verlengstuk van die ander, byvoorbeeld só dat die vraag van die een onmiddellik en direk deur die ander beantwoord word nie. Omdat die twee dissiplines gedeeltelik as't ware oormekaar skuif, beteken dit eerder ' $n$ indirekte aansluiting, 'n dinmiese wisselwerking, 'n dialoog vanuit twee verskillende perspektiewe die vraag moet vertaal word in die taal van die ander, beantwoord word en terugvertaal word. Dit is 'n dialektiese verhouding.

10.3. Ten diepste is die teologie die veronderstelling van die sosiologie, in soverre die sosiologie dit nodig het om herinner te word aan sy eie horison (inperkend en ruimteskeppend bedoel). Dit is die diens van die teologie aan die sosiologie.

10.4. Omdat elke teologie deel het aan die menslikheid en profaniteit van alle wetenskapsbeoefening, kan dit (tot sy eie loutering!) onderwerp word aan 'n kennissosiologiese analise ten aansien van die sosiaal-historiese voorveronderstellinge daarvan. 
11. Waarmee die sosiologie gekonfronteer word, is nie slegs die geloof (as gesindheid, intuisie, fides qua creditur) nie; maar ook die teologie (as verantwoorde geloof, fides quac creditur).

12. Dit lê nie op die terrein van die teologie as sodanig om empiriese sosiale navorsing te doen nie.

13 Die kerk behoort hom deeglik te vergewis van die sosiologiese siening van enige situasie waarin hy eties betrokke is. Die etiese beslissing kan slegs geskied met inagneming van die (suiwer, sober) teologiese én die (suiwer, sober) sosiologiese inbreng. Die praktiese etiese beslissinge van die kerk oor maatskaplike vraagstukke is nie siegs vóor-wetenskaplik nie, maar ná-wetenskaplik ${ }^{1}$ ) (net soos die preke van dominees).

14. Barth staan oop vir die aanwysing deur sosiologiese navorsing van bepaalde reëlmatighede in die tussenmenslike gedraginge (op grond waarvan gespreek word van sogenaamde ekonomiese/politieke "wette"), maar hierdie "wette" is slegs "tussen hakies," geldig, dit wil sê geldig binne die referensiekader van die sosiologie (slegs relatief geldig) en kan dus nie sondermeer aanspraak maak op geloof en gehoorsaamheid nie.

15. Barth hou rekening met die voorkoms van goeie, regte etiek, ook by nie-christelike voorveronderstellinge, maar hy verlaat hom nie by voorbaat en toe-oë daarop as 'n vanselfsprekende bolwerk in die etiek nie. Die oordeel dat so 'n etiek goed iś, is 'n latere bevestiging aan die hand van die één Kriterium, wat nie beteken 'n vooraf ontruiming van die veld of 'n gedeelte van die veld, deur die teologie nie.

16. Die vashou aan die Heilige Skrif beteken nie dat Barth probeer om direk sekere sosiale strukture wat in die Bybel voorkom, in 'n moderne, totaal-ander situasie te kopieer nie. Dit sou neerkom op biblisisme wat nie reg laat geskied aan die historisiteit van die Heilige Skrif nie (vgl. probleem van die scopus van die Skrif).

\section{SLOT:}

Soos in die vooropmerking gesê is, en hopelik uit die res die verhaal geblyk het, is hierdie 'n onderwerp wat dit verdien om teologies breër, sosiaal meer konkreet, en deurlopend bewerk te word.

Daarom wil ek afsluit met 'n voorstel, naamlik dat die kongres 'n studiekommissie in die lewe roep, met die doel om in samewerking met sosioloë, op hierdie terrein verder te arbei aan die hand van 'n bepaalde tema wat die kommissie self kan bepaal.

1. Daarmee neem ek die onderskeiding van prof. dr. P. S. Dreyer oor in sy referaat: Die grense van die wetenskap, in: Die Waardes van die Afrikaner, 62-72. 